\title{
THE EMESINE ASSASSIN BUG GENUS EMESOPSIS (HETEROPTERA: REDUVIIDAE) FROM JAPAN
}

\begin{abstract}
Ishikawa, T. \& T. Yasunaga, 2004. The emesine assassin bug genus Emesopsis (Heteroptera: Reduviidae) from Japan. - Tijdschrift voor Entomologie 147: 221-228, figs. 1-29. [ISSN 00407496]. Published 1 December 2004.

The reduviid genus Emesopsis of Japan is revised. Four species are recognized. Two new species, E. impar and E. kazutakai, are described, and E. plagiata Miller is reported from Japan for the first time. Emesopsis nubila Uhler, which was once captured at plant quarantine of the Port of Tokyo, is confirmed to occur on Ishigaki Island of the Ryukyus.

Tadashi Ishikawa (corresponding author), Laboratory of Insect Resources, Faculty of Agriculture, Tokyo University of Agriculture, Funako 1737, Atsugi, Kanagawa, 243-0034 Japan. Email: chuishikawa@hotmail.com

Tomohide Yasunaga, Zoological Laboratory, Department of Science, Faculty of Education, Okayama University, Tsushimanaka 3-1-1, Okayama, 700-8530 Japan.

Key words. - Heteroptera; Reduviidae; Emesinae; Ploiariolini; Emesopsis, Japan; new species.
\end{abstract}

Emesopsis Uhler, 1894 is a morphologically diverse assassin bug genus in the tribe Ploiariolini of the subfamily Emesinae, comprising 19 species from the Oriental and Australian regions, inclusive of the tropicopolitan E. nubila Uhler, 1894 (Maldonado Capriles 1990). This genus is characteristic in having the foretarsus less than one-fourth as long as the foretibia and the hemelytron with a small quadrate basal cell situated at inner anterior angle of discal cell.

Two accidentally introduced individuals of Emesopsis nubila were once found at the plant quarantine of the Port of Tokyo (Hasegawa 1962). Since then no reliable record on Emesopsis has been associated with Japan. In a series of Emesopsis specimens recently collected from Japan, we recognized four species; two of them were identified as E. nubila and E. plagiata Miller that has been known from the Peninsular Malaysia and the Philippines, and the others were not corresponding to any known congeners.

In this paper, we describe two new species, $E$. impar from the Ryukyus and E. kazutakai from Kyushu and the Ryukyus. The previously described species, $E$. plagiata and E. nubila, are diagnosed. A key is provided for facilitating identification.

All measurements are given in $\mathrm{mm}$. The material examined in this study is preserved in the Zoological Laboratory, Faculty of Education, Okayama University, Okayama, Japan. Collectors of material examined here are abbreviated as follows: KT: Keiichi Takahashi; KY: Kazutaka Yamada; MT: Mikio Takai; TI: Tadashi
Ishikawa; TN: Tadafumi Nakata; TT: Tomoyuki Tsuru. Terminology generally follows that of Wygodzinsky (1966).

\section{TAXONOMY}

\section{Genus Emesopsis Uhler}

Emesopsis Uhler, 1894: 718 (n. gen.), type species by monotypy: Emesopsis nubilus Uhler, 1894.

Calphurnia Distant, 1909: 502, type species by monotypy: Calphurnia reticulata Distant, 1909 (= Emesopsis nubila Uhler, 1894) (syn. by Wygodzinsky \& Usinger 1960: 243).

Hadrocranella Horváth, 1914: 647, type species by monotypy: Hadrocranella imbellis Horváth, 1914 (syn. by Wygodzinsky \& Usinger 1960: 243).

Emesopsis (Hadrocranella): McAtee \& Malloch, 1926: 119.

This genus is easily recognized by a combination of such characters as the head and thorax usually with densely distributed, long, woolly, reclining setae; the rostral segment II distinctly swollen; the pronotum not carinate laterally; the metanotum with a spine; the forefemoral spines much shorter than width of the forefemur; the foretarsus less than one-fourth as long as the foretibia; the hindwing with a distinct hamus; the hemelytron with a small, quadrate basal cell situated laterally at base of a discal cell; and the pygophore with a posterior process. Wygodzinsky (1966) provided a detailed description. 


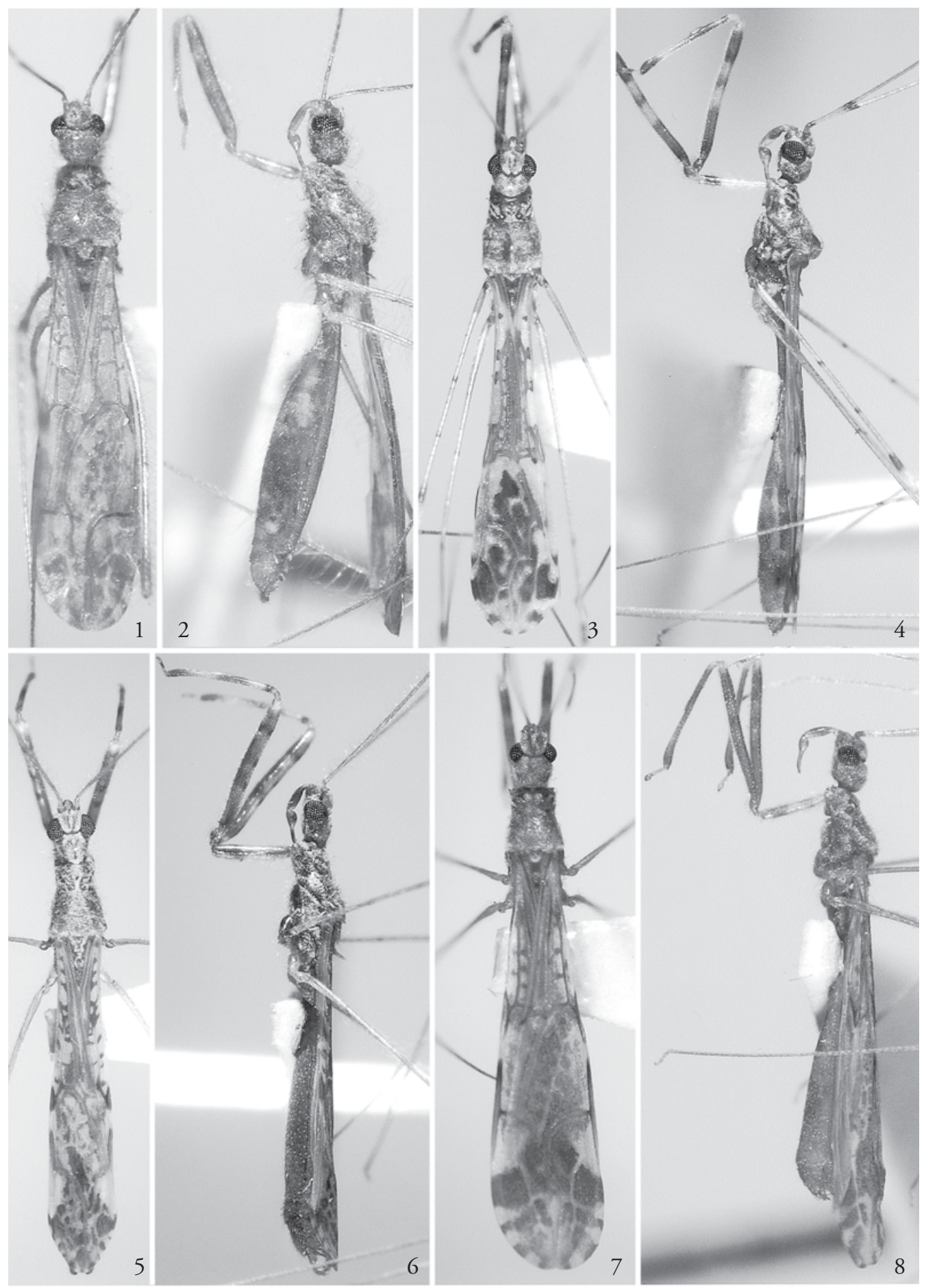

Figs. 1-8. Emesopsis spp., dorsal (1, 3, 5, 7) \& lateral (2, 4, 6, 8) views. - 1, 2, E. nubila, male; 3, 4, E. plagiata, female; 5, 6, E. impar sp. n., male (holotype); 7, 8, E. kazukatai sp. n., male (holotype). 
Emesopsis nubila Uhler

(figs. 1, 2)

Emesopsis nubilus Uhler, 1894: 718 (n. sp.).

Calphurnia reticulata Distant, 1909: 503 (syn. by Wygodzinsky \& Usinger 1960: 248).

Calphurnia pacalis Horváth, 1914: 649 (syn. by Wygodzinsky \& Usinger 1960: 248).

Ploiariola pallida Jeannel, 1919: 151 (syn. by Wygodzinsky \& Usinger 1960: 248).

Emesopsis pilosus Usinger, 1946: 42 (syn. by Wygodzinsky \& Usinger 1960: 248).

Diagnosis. - Recognized by the head, thorax and legs with long erect setae, the posterior pronotal lobe twice of the anterior pronotal lobe, and the hemelytron iridescent with rather obscure small markings. Body length about $4.5 \mathrm{~mm}$. Wygodzinsky (1966) provided many illustrations of the species including male and female genitalia.

Distribution. - Tropicopolitan, Japan: the Ryukyus (Ishigaki Island).

Remarks. - A fresh male of Emesopsis nubila examined in this study represents a new record from Ishigaki Island. This species was once found at the plant quarantine of the Port of Tokyo; two individuals were accidentally introduced with shipments from the Naha Port of Okinawa Island (Hasegawa 1962). Therefore, the species may occur on Okinawa Island.

Material examined. - JAPAN: Ishigaki Is.: Mt. Omoto-dake: $10^{\text {t }}$ (shown in figs. 1, 2), 6.vi.2001, KY.

\section{Emesopsis plagiata Miller \\ (figs. 3, 4) \\ Emesopsis plagiatus Miller, 1941: 777 (n. sp.).}

Diagnosis. - Easily separable from other members of Emesopsis by the head, thorax and legs without long erect setae, the antennal segment I with four brown annulations, the pronotum conspicuously elevated at middle near posterior margin, and the mid and hind femora each with three brown annulations. Body length 4.9-5.6 $\mathrm{mm}$.

Distribution. - Japan: the Ryukyus (Ishigaki Island, Iriomote Island, Yonaguni Island); China, Philippines, Peninsular Malaysia. This species is recorded from Japan for the first time.

Remarks. - This species, in most cases, was found on dead leaves and branches of broad-leaved trees. All individuals from Yonaguni Island were collected from dead, drooping leaves of Livistona chinensis var. subglobosa (Hassk.) (Palmae).

Material examined. - JAPAN: Ishigaki Is.: Hirakubo: 1 to 1 ㅇ, 13.iii.2003, TN. Iriomote Is.: Uehara: 1 ㅇ (shown in figs. 3, 4), 14.v.2002, KY; Shirahama-rindô: $10^{\star}, 8 . v i .2002$, TT. Yonaguni Is.: Mt. Kubura-dake: 2우, 29-31.v.2003, TT; 2 오 5오, 31.v.-1.vi.2003, TI.

\section{Emesopsis impar sp. n.}

(figs. 5, 6, 9-17)

Type material. - Holotype ô (type no. ZEOU-RE-1), Mt. Kubura-dake, Yonaguni Is., the Ryukyus, 31.v.2003, TI. - Paratypes: JAPAN: Miyako Is.: Mt. Nobaru-dake, Ueno-son: 1 ơ 1우 13.x.1999, TI; Agarisokobaru, Higashinakasonezoe, Hirara: 10, 2.xi. 1999, TI. Ishigaki Is.: Urasoko-nôdô: 1 đ̃, 6.iii. 1999, KT; 1 đै, 10.vi.2003, TT; Ôzato: 1 ô, 20.iii. 2001, MT; Fukaiomoto: 19 , 16.vi.2002, TT; Takeda-rindô: 1 , 13.vi.2003, TI; 1 , 4. 4.vi.2003, TT; Omoto: 1 , 14.ii.1999, KT; 1 \$, 30.iii.2002, KY; 3 9, 16.v. 2002, KY; 2 † 3 ㅇ, 27.x.2002, KY; 2 , 4.vi.2003, TT; 1 으, 11.vi.2003, KY; Shiramizu: 2q, 2.x.2002, KY; $10^{\star}$ (shown in figs. 13-16), 8.vi.2003, тT; 2 \% , 14.vi.2003, TT; Mt. Yarabu-dake: 19 , 4.vi.2003, MT. Iriomote Is. Uehara: 1 ㅇ, 14.v.2002, KY; Funaura: 1 ㅇ, 15.v.2002, KY; 1 우, 19.v.2002, MT; Haemi: 10ิ, 14.v.2002, KY. Yonaguni Is.: Mt. Kubura-dake: 101 क , 30.v.2003,

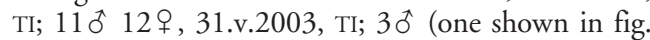
10) 6 ㅇ (one shown in fig. 17), 1.vi.2003, TI.

Diagnosis. - Recognized by the head and pronotum covered with long erect setae intermixed with woolly reclining setae, the male antennal segment I with long erect setae and short curved setae, the posterior pronotal lobe less than twice as long as the anterior pronotal lobe, the spiny scutellum, the spineshaped posterior process of the pygophore (fig. 13), the strongly curved parameres (fig. 14), and the symmetrical endosoma of the phallus (figs. 15, 16).

Description. - Male: coloration (figs. 5, 6): body generally dark brown. Dorsum of head and disc of pronotum brownish yellow. Antennal segment I pale yellow; segment II brownish yellow; segments III and IV brown. Rostrum dark brown, with basal part of segment III and apical parts of segments I and II pale. Scutellar and metanotal spines brownish yellow. Foreleg (fig. 11) brownish yellow; coxa dark brown at base and on apical $1 / 3$; trochanter dark brown; femur darkened basally, decorated with incomplete dark brown annulations at basal $2 / 5$, apical $2 / 5$ and apical $1 / 5$, and with whitish apex; tibia darkened on apical $1 / 5$, with broad dark brown annulation near middle, and narrow dark brown annulation at basal $1 / 10$; tarsal segment II brown medially. Mid- and hindlegs brownish yellow; femur weakly darkened apically; tibia gradually dark apicad; tarsal segment II brown; coxa and trochanter of midleg dark brown. Hemelytron brownish yellow, decorated with about 10 transverse, vein-like, dark brown markings on basal half, and with many small dark brown markings on apical half as shown in fig 10. Abdomen uniformly dark brown.

Structure: head (fig. 9) furnished with long erect se- 


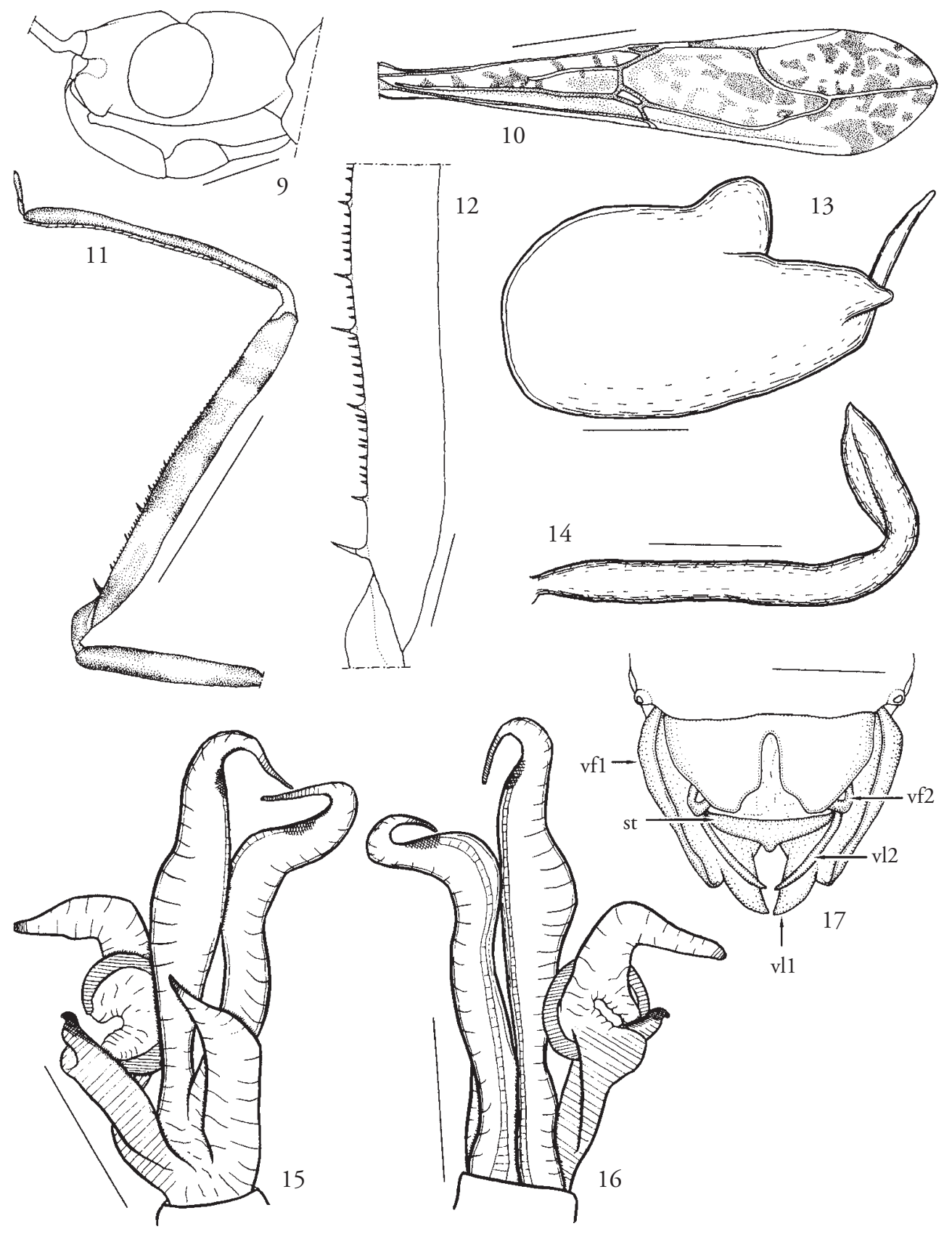

Figs. 9-17. Emesopsis impar sp. n. (setae omitted). - 9, head, lateral view (holotype); 10, right hemelytron; 11, foreleg (holotype); 12, basal part of forefemur (holotype); 13, pygophore, lateral view; 14, left paramere, lateral view; 15, 16, endosoma of phallus, dorsal (15) \& ventral (16) views; 17 , female genitalia, dorsal view ( $v f 1$ : valvifer I, $v f 2$ : valvifer II, $v l 1$ : valvula I, $v l 2$ : valvula II, st: styloides). Scales: $1.0 \mathrm{~mm}$ for $10 \& 11,0.2 \mathrm{~mm}$ for $9,12-17$. 
tae densely intermixed with woolly reclining setae, and with small tubercle at middle behind interocular furrow; anteoculus slightly shorter than postoculus; interocular furrow weakly sinuate. Eye large, prominent laterad, not reaching level of ventral surface of head in lateral view, 1.3 times as wide as interocular space in dorsal view. Antennal segment I covered with short curved setae intermixed with long erect setae; segments II, III and IV with short reclining setae; proportion of segments I to IV 13: 11: 4: 2. Rostral segment I covered with curved setae on outer surface; segments II and III sparsely furnished with short suberect setae; proportion of segments I to III 11: 5: 7.

Pronotum 1.2 times as long as head, 1.2 times as long as humeral width, covered with long erect setae intermixed with woolly reclining setae; anterior lobe with some pairs of glabrous areas discally; posterior lobe 1.5 times as long as anterior lobe, with anteriorly arcuate posterior margin. Scutellum apically with spine horizontally produced posteriad. Metanotal spine erect, with acute apex.

Foreleg (figs. 11, 12) densely furnished with short, reclining and suberect setae; coxa about 7 times as long as its maximum width; femur twice as long as coxa, about 11 times as long as its maximum width, with anteroventral and posteroventral series of 1 large, about 5 medium-sized and about 60 small spines each; basal spine of them largest; tibia 0.8 times as long as femur; tarsi 2-segmented, 0.15 times as long as tibia. Mid- and hindlegs slender; femur with long erect setae basally and short reclining setae on remaining surface; tibia with short reclining setae. Hemelytron (fig. 10) just reaching or exceeding apex of abdomen; basal cell rectangular; $\mathrm{M}$ and $\mathrm{Cu}$ veins proximal to discal cell not forming elongate subbasal cell, but connected by transverse, vein-like, dark brown markings; $M$ vein distal to discal cell without bifurcate branch.

Abdomen furnished with short, reclining and suberect setae; tergite I with erect spine. Pygophore (fig. 13) twice as long as its height, posterolaterally projected triangularly; posterior process (fig. 13) long, spine-shaped, slightly curved posteriad, with obtuse apex. Paramere (fig. 14) large, compressed laterally, strongly curved in apical part, pointed at apex, with erect and suberect setae variable in length. Endosoma of phallus (figs. 15, 16) asymmetrical, with left-lateral and right-lateral expansions in addition to a pair of vesica arms; left-lateral expansion membranous, simple in form, sclerotized apically, with acute apex; right-lateral expansion weakly sclerotized basally, equipped with ring-like sclerites at middle, membranous apically, obtuse at apex, with semi-sclerotized expansion arising near base; vesica arm sclerotized on apical part, acute at apex.

Female: almost the same in general appearance as male. Eye as wide as interocular space in dorsal view.
Antennal segment I covered with short curved setae only. Pronotum 1.3 times as long as head, 1.4 times as long as humeral width. Abdomen apically narrowed and rounded. Tergite IX (fig. 17) deeply incised medially. Valvifers I (fig. 17) roughly pentagonal, apically rounded; valvulae I (fig. 17) small, triangular, subacute subapically. Valvulae II (fig. 17) rod-shaped, tapering. Styloides (fig. 17) completely fused, transversely bandshaped, roundly projected posteriad at middle.

Measurements (holotype). - Body length 6.1 (paratypes: 5.4-6.2 in male, 5.4-6.3 in female). Head length including neck 1.09; width across eyes 0.65; interocular space 0.20. Antenna length 7.51; lengths of segments I, II, III and IV 3.27, 2.71, 1.03 and 0.50. Rostrum length 0.9; lengths of segments I, II and III $0.43,0.20$ and 0.27 . Pronotum length 0.93 ; width across humeri 0.74 . Hemelytron length 4.39. Lengths of femur, tibia and tarsus of foreleg 1.94, 1.47 and 0.23 ; of midleg 3.15, 4.28 and 0.17 ; of hindleg 4.87, 6.55 and 0.19 , respectively. Abdomen length 3.68.

Distribution. - Japan: the Ryukyus (Miyako Island, Ishigaki Island, Iriomote Island, Yonaguni Island).

Etymology. - From Latin, impar (= unequal), referring to the asymmetrical endosoma; an adjective.

Remarks. - This new species resembles Emesopsis aberrans (Distant, 1909) known form Sri Lanka and E. spicata McAtee \& Malloch, 1926 from the Philippines, in having the posterior pronotal lobe less than twice as long as the anterior pronotal lobe, the spined scutellum, the strongly curved paramere, and the spine-shaped posterior process of the pygophore. However, this new species can be distinguished from them by the head and pronotum furnished with long erect setae intermixed with woolly reclining setae, the male antennal segment I furnished with long erect setae intermixed with short curved setae, and the asymmetrical endosoma of the phallus (figs. 15, 16).

This species was often found from dead leaves and branches of broad-leaved trees, and simultaneously collected with the preceding species, Emesopsis plagia$t a$, in Yonaguni Island. In Miyako Island, several individuals were found from broad-leaved shrub.

\section{Emesopsis kazutakai sp. n.}

(figs. 7, 8, 18-29)

Type material. - Holotype ô (ZEOU-RE-2), Mt. Taka-dake, Isahaya-shi, Nagasaki Pref., Japan, 4.x.2001, KY. - Paratypes: JAPAN: Amami-oshima Is.: Kinsakubaru, Naze: 10 (shown in figs. 22-25) 1 q (shown in fig. 19), 11.ix.2002, KY; Yakukatsu, Sumiyô-son: 2 ㅇ (one shown in fig. 26), 15.ix.2002, KY. Okinawa Is.: Yona, Kunigami-son: 1 o (shown in figs. 27-29), 23.iii.2002, KY. 

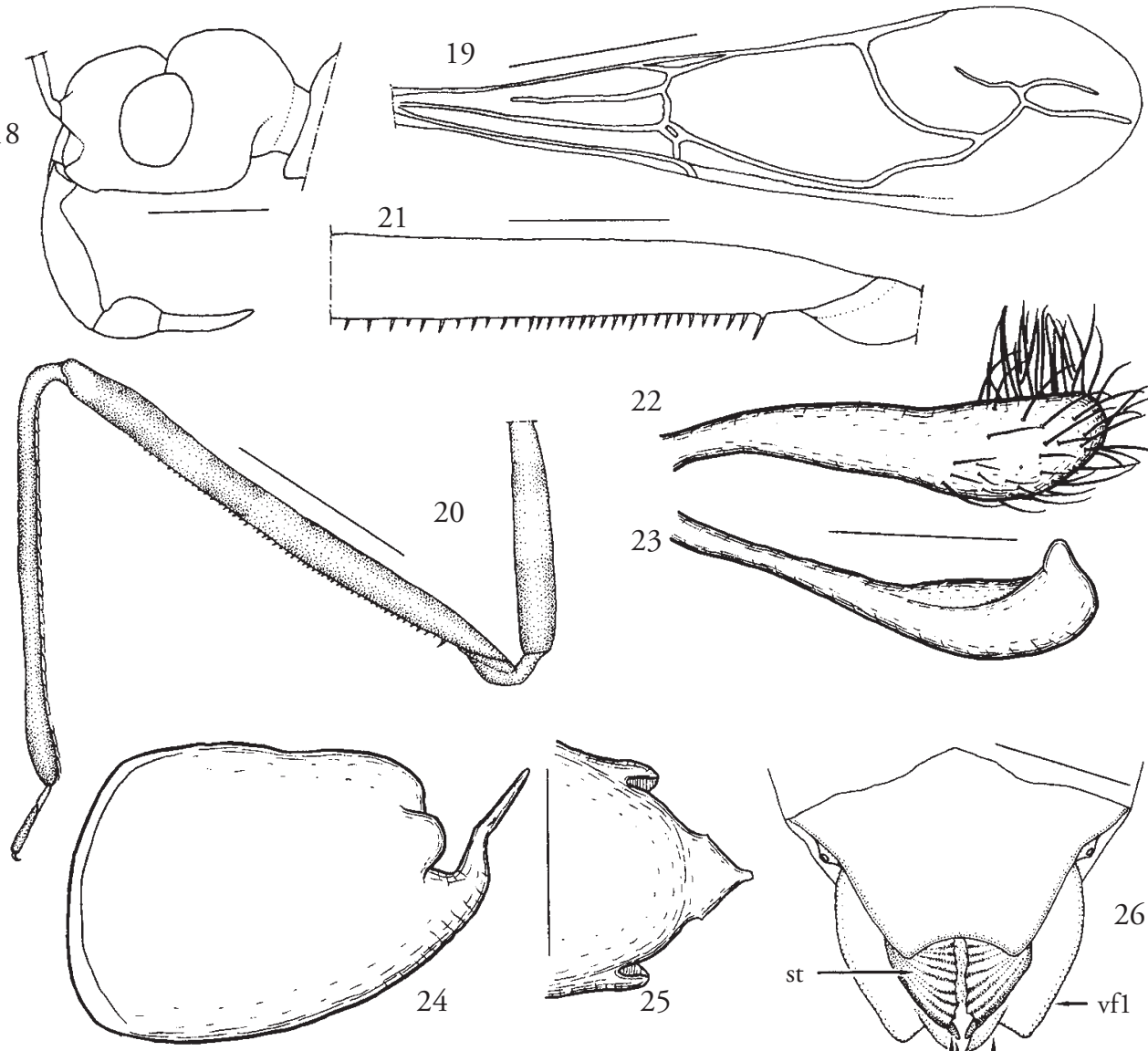

22
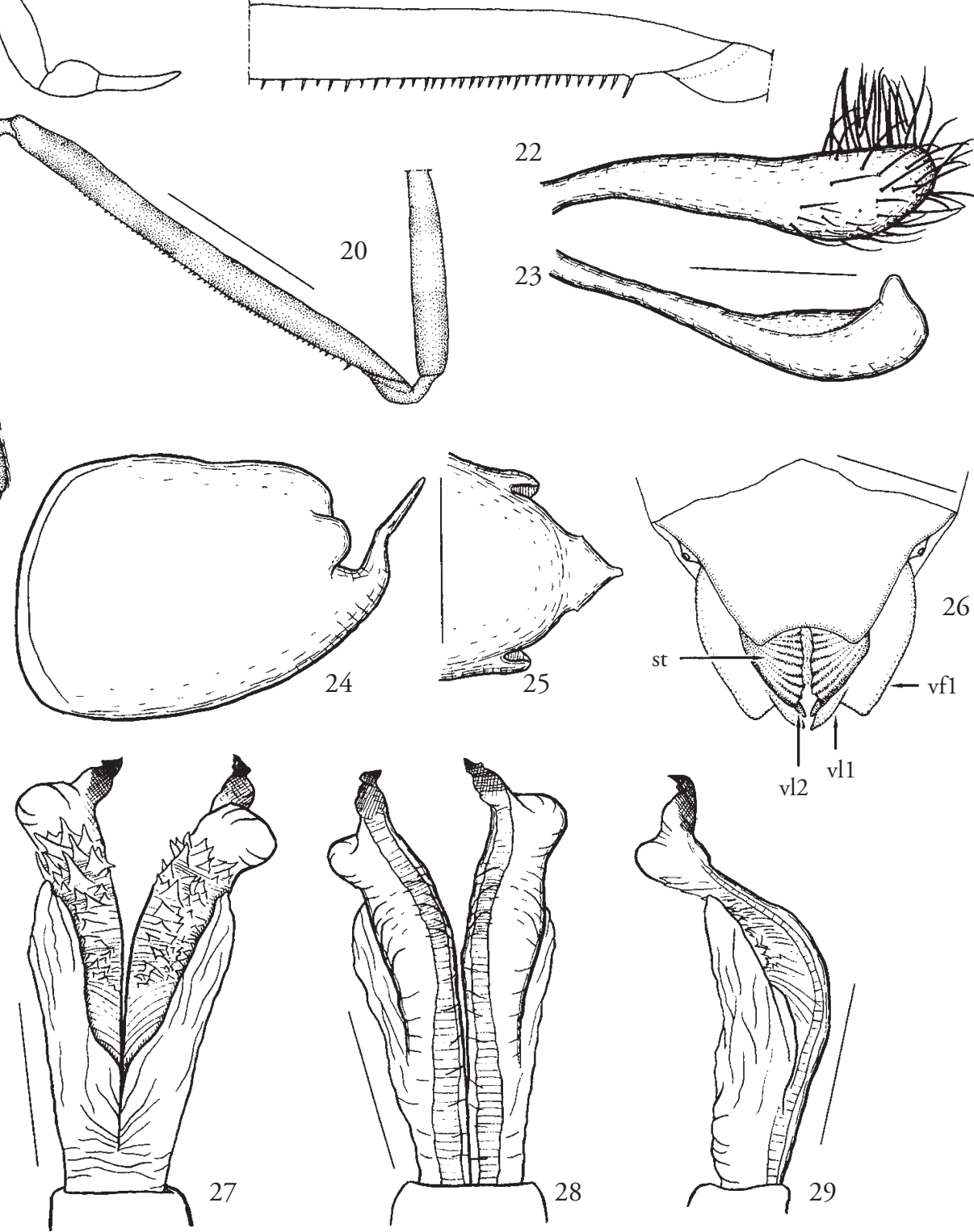

vl2

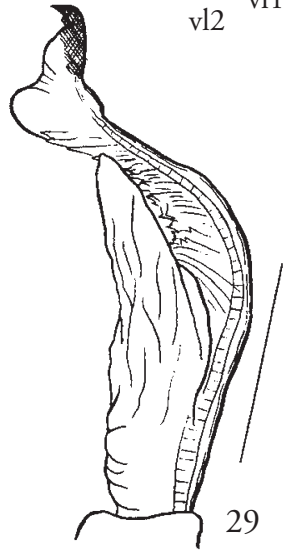

Figs. 18-29. Emesopsis kazutakaisp. n. (setae omitted except for fig. 22). — 18, head, lateral view (holotype); 19, right hemelytron, indicating venation only; 20, foreleg (holotype); 21, basal part of forefemur (holotype); 22, 23, left paramere, lateral (22) and dorsal (23) views; 24, pygophore, lateral view; 25, apical part of pygophore, ventral view; 26, female genitalia ( $v f 1$ : valvifer I, $v l 1$ : valvula I, vl2: valvula II, st: styloides); 27-29, endosoma of phallus, dorsal (27), ventral (28) \& left-lateral (29) views. Scales: $1.0 \mathrm{~mm}$ for $19,0.5 \mathrm{~mm}$ for $20,0.2 \mathrm{~mm}$ for $18,21,24-26,0.1 \mathrm{~mm}$ for 22, 23, 27-29. 
Diagnosis. - Recognized by the head and pronotum covered with long erect setae intermixed with woolly reclining setae, the head strongly constricted ventrally near base in lateral view (fig. 18), the anterior pronotal lobe with a pair of $\mathrm{V}$-shaped glabrous areas, the mid- and hindlegs with reclining setae only, the hemelytron punctuate on dark markings, the posterior process of the pygophore triangular with minute projection near base of each side (fig. 25), the endosoma of the phallus with a single pair of membranous expansions (figs. 27-29), and the vesica arms with many dorsal triangular projections (fig. 27).

Description. - Male: coloration (figs. 7, 8): body generally brown. Antenna yellowish brown to brown, with dark annulations at base and subapical part of segment I. Rostrum brownish yellow; segment I medially brown. Forelegs (fig. 20) yellowish brown to brown; coxa pale on basal $1 / 5$ and at middle; femur decorated with pale annulations at middle and apical $3 / 10$, and with apex whitish; tibia broadly pale on subbasal and subapical parts, with base whitish; tarsi yellowish brown. Mid- and hindlegs yellowish brown; femur with brown annulation subapically; tarsus brownish yellow. Hemelytron brownish yellow, mottled with many brown markings, and with about 5 transverse, vein-like, dark brown markings on basal half; punctures on dark brown markings brownish yellow. Abdomen yellowish brown, darkened basally.

Structure: head (fig. 18) strongly constricted ventrally near base in lateral view, sparsely furnished with long, erect and suberect setae densely intermixed with short reclining setae; anteoculus 0.6 times as long as postoculus; interocular furrow weakly arcuate posteriad. Eye prominent laterad, not reaching level of ventral surface of head in lateral view, 0.6 times as wide as interocular space in dorsal view. Antenna with reclining setae; proportion of segments I to IV 11: 8: 4: 3 . Rostrum sparsely covered with short setae; proportion of segments I to III 5: 2: 3 .

Pronotum 0.9 times as long as head, 1.1 times as long as humeral width, sparsely covered with long erect setae intermixed with woolly reclining setae; anterior lobe with a pair of large, $\mathrm{V}$-shaped, glabrous areas; posterior lobe twice as long as anterior lobe; posterior margin anteriorly arcuate at middle. Scutellum without spine apically. Metanotal spine short, robust, with obtuse apex.

Foreleg (figs. 20,21) with erect and suberect setae variable in length; coxa 6.5 times as long as its maximum width; femur 2.2 times as long as coxa, about 14 times as long as its maximum width, with anteroventral and posteroventral series of 60 to 70 small spines each; basal spine of posterolateral series largest; tibia 0.8 times as long as femur; tarsus 2-segmented, 0.15 times as long as tibia. Mid- and hindlegs slender, with reclining setae. Hemelytron (fig. 19) exceeding apex of abdomen by about one-sixth as long as its length, with a number of fine punctures on dark brown markings; basal cell rectangular; $\mathrm{M}$ and $\mathrm{Cu}$ veins proximal to discal cell not forming elongate subbasal cell; $\mathrm{M}$ vein distal to discal cell with bifurcate branch.

Abdomen furnished with short reclining setae; tergite I with erect spine. Pygophore (figs. 24, 25) 1.5 times as long as its height, posterolaterally projected roundly; posterior process (figs. 24, 25) triangular, obtuse at apex, with minute tubercle near base of each side. Paramere (figs. 22, 23) expanded apically, curved in apical part, rounded at apex, with erect and suberect setae variable in length. Endosoma of phallus (figs. 2729 ) with a pair of dorsal expansions in addition to a pair of vesica arms; dorsal expansion membranous, simple in form, shorter than vesica arm; vesica arm upturned at middle, dorsally armed with a number of triangular projections, expanded at subapical part, twisted and sclerotized in apical part, with acute apex.

Female: almost the same in general habitus as male. Eye 0.7 times as wide as interocular space in dorsal view. Pronotum as long as head and as long as humeral width. Abdomen apically narrowed and rounded. Valvifers I (fig. 26) roughly triangular, rounded apically; valvulae I (fig. 26) small, triangular, obtuse at apex. Valvulae II (fig. 26) slender, rod-shaped. Styloides (fig. 26) large, not fused, crimpled transversely, sclerotized along ridges of these crimples.

Measurements (holotype). - Body length 4.4 (paratypes: 4.3-4.5 in male, 4.4-4.8 in female). Head length including neck 0.60 ; width across eyes 0.43 ; interocular space 0.19 . Antenna length 6.48 ; lengths of segments I, II, III and IV 2.63, 2.07, 1.04 and 0.74 . Rostrum length 0.70 ; lengths of segments I, II and III $0.35,0.14$ and 0.21 . Pronotum length 0.54 ; width across humeri 0.51 . Hemelytron length 3.87 . Lengths of femur, tibia and tarsus of foreleg 1.39, 1.12 and 0.17; of midleg 2.50, 3.36 and 0.16 ; of hindleg 3.56, 5.01 and 0.17 , respectively. Abdomen length 2.82 .

Distribution. - Japan: Kyushu (Nagasaki Pref.), the Ryukyus (Amami-oshima Island, Okinawa Island). The type locality of this species (Nagasaki Prefecture, Kyushu) is the northernmost record within the distributional range of the genus Emesopsis in natural condition.

Etymology. - Named after Mr. Kazutaka Yamada, who collected all the type specimens of this new reduviid; a noun in genitive case.

Remarks. - This new species is the most similar in general appearance to Emesopsis scitula Wygodzinsky \& Usinger, 1960 known from Caroline Islands, as having the head strongly constricted ventrally near base in lateral view, the medially brown rostral segment I, the shape of glabrous areas on the pronotum, the color pattern of the hemelytron, and the triangular posterior process of the pygophore. However, the pre- 
sent new species is separable from it by the head with long erect setae intermixed with woolly reclining setae, the antennal segment I with a dark subapical annulation, the forefemur about 14 times as long as its maximum width (fig. 20), the hemelytron punctuate on dark markings, the endosoma with a single pair of membranous expansions in addition to the vesica arms (figs. 27-29), and the vesica arm with many dorsal triangular projections (fig. 27).

According to Mr. K. Yamada (pers. comm.), the present new species was collected from dead leaves and branches of broad-leaved trees. No other information is available on the biology.

\section{KEY TO THE JAPANESE SPECIES OF EMESOPSIS}

1. Pronotum conspicuously elevated at middle near posterior margin; head without long erect setae .. E. plagiata

- Pronotum not elevated at middle near posterior margin; head more or less with long erect setae ...

2. Scutellum with a spine apically; posterior pronotal lobe less than twice as long as anterior pronotal lobe

E. impar

- Scutellum without spine apically; posterior pronotal lobe twice as long as anterior pronotal lobe.

3. Mid- and hindlegs with long erect setae; hemelytron with rather obscure markings; markings on hemelytra not punctuate .......................... E. nubila

- Mid- and hindlegs without long erect setae; hemelytron with dark markings; dark markings on hemelytra punctuate. E. kazutakai

\section{ACKNOWLEDGMENTS}

We are much indebted to the following individuals for kindly providing the material used in this study: Dr. K. Takahashi (Bureau of Agriculture, Republic of Palau), and Messrs M. Takai (Kochi Agricultural Research Center, Nankoku), T. Nakata (Japan Interna- tional Research Center for Agricultural Science, Ishigaki, Okinawa), K. Yamada (Osaka Prefecture University) and T. Tsuru (Tokyo University of Agriculture). Our thanks also due to Dr. E. J. van Nieukerken (National Museum of Natural History, Leiden) and Dr. M. D. C. Coscaron (Museo de Ciencias Naturales de La Plata) for reviewing the manuscript with useful comments and suggestions.

\section{REFERENCES}

Distant, W. L., 1909. Rhynchotal notes. 65. Oriental Rhynchota Heteroptera. - Annals and Magazine of Natural History (8) 3: 491-507.

Hasegawa, H., 1962. [Emesopsis nubilus Uhler found at the Port of Tokyo.] - Rostria (1): 1-2. [In Japanese]

Horváth, G., 1914. Miscellanea Hemipterologica. XIIIXVII. - Annales Historico-Naturales Musei Nationalis Hungarici 12: 623-660.

Jeannel, R., 1919. Insectes Hémiptères 3. Henicocephalidae et Reduviidae. - In: Voyage de Ch. Alluaud et R. Jeannel en Afrique Orientale (1911-1912). Résultats scientifiques: 131-314, plates 5-12; L. Lhomme, Paris.

Maldonado Capriles, J., 1990. Systematic catalogue of the Reduviidae of the World (Insecta: Heteroptera). Caribbean Journal of Science, Puerto Rico, x+694 pp.

Miller, N. C. E., 1941. New genera and species of Malaysian Reduviidae. Supplementary Records. - Journal of the Federated Malay States Museum 18: 774-804.

Uhler, P. R., 1894. A list of Hemiptera-Heteroptera collected in the island of St. Vincent by Mr. Herbert H. Smith, with descriptions of new genera and species. - Proceedings of the Zoological Society of London 1893: 705-719.

Usinger, R. L., 1946. Hemiptera-Heteroptera of Guam. Insects of Guam 2. - Bulletin Bernice P. Bishop Museum 189: 11-103.

Wygodzinsky, P., 1966. A monograph of the Emesinae (Reduviidae, Hemiptera). - Bulletin of the American Museum of Natural History 133: 1-614.

Wygodzinsky, P. \& R. L. Usinger, 1960. Heteroptera: Reduviidae. - Insects of Micronesia 7: 231-283.

Received: 15 September 2003

Accepted: 17 February 2004 